This item was submitted to Loughborough's Research Repository by the author.

Items in Figshare are protected by copyright, with all rights reserved, unless otherwise indicated.

\title{
From neglect to selective engagement: The EU approach to rural development in the Arab Mediterranean after the Arab uprisings
}

PLEASE CITE THE PUBLISHED VERSION

https://doi.org/10.1080/13629395.2017.1358897

\section{PUBLISHER}

(C) Taylor \& Francis

\section{VERSION}

AM (Accepted Manuscript)

\section{PUBLISHER STATEMENT}

This work is made available according to the conditions of the Creative Commons Attribution-NonCommercialNoDerivatives 4.0 International (CC BY-NC-ND 4.0) licence. Full details of this licence are available at: https://creativecommons.org/licenses/by-nc-nd/4.0/

\section{LICENCE}

CC BY-NC-ND 4.0

\section{REPOSITORY RECORD}

Kourtelis, Christos. 2019. "From Neglect to Selective Engagement: The EU Approach to Rural Development in the Arab Mediterranean After the Arab Uprisings". figshare. https://hdl.handle.net/2134/32525. 


\title{
From Neglect to Selective Engagement: The EU Approach to Rural Development in the Arab Mediterranean after the Arab Uprisings
}

\author{
Word count: 8,974 words
}

\begin{abstract}
After the Arab uprisings, the EU designed a new regional programme for the development of the agricultural sector of the European Neighbourhood Policy (ENP) partners. The European Neighbourhood Programme for Agriculture and Rural Development (ENPARD) is based on an integrated logic for rural development. This new conceptual framework advocates multi-sectoral planning and the active participation of local actors in the decision-making process in order to promote inclusive growth and to support small and medium enterprises (SMEs). This approach aims to contribute to the security and stability of the rural areas of the Arab Mediterranean partners (AMPs). This paper analyses ENPARD and it argues that the inclusion of new actors in the design of the programme has partially challenged established views of policymakers within the EU. However, EU engagement in this area is still determined by a hierarchical mode that puts local actors at the bottom of the decision-making process and it is driven by a technocratic ratchet mechanism that fits new information into existing cognitive frames. Despite some positive changes in national policies the paper claims that this type of technocratic engineering does not change social relations in rural areas and it undermines the success of the programme.
\end{abstract}

Keywords: ENPARD; ENP; agriculture; selective engagement; small and medium enterprises; integrated rural development

\section{Introduction}

After the Arab revolts, the EU announced a new ENP aiming to make the policy more objective and effective. The new ENP was followed by a new rhetoric, which underlined the need for more jobs and inclusive growth (European Commission, 2011a, 2012a). For the development of the agricultural sector of the ENP partners the EU tried to improve the effectiveness of the policy by designing ENPARD. ENPARD was launched in 2012 and it works parallel to the Association Agreements (AAs), as it supports the modernisation of the agricultural sector of the AMPs and as part of the ENP seeks to prepare these countries for a greater stake in the EU market. Yet, ENPARD does not focus on trade issues or border controls. It is a regional programme that attempts to increase the economic and political stability of rural areas by improving the organisational capacity of the ENP countries, the livelihoods of vulnerable groups and by supporting small farmers. Through ENPARD the EU claims that it adopts an integrated approach for the rural development of the AMPs. This 
approach has already been established in the member states since the mid-1980s, and it has helped small farmers in the EU and candidate countries to improve their livelihoods.

This contribution analyses the work of ENPARD in the AMPs. The paper argues that while the EU's perception of the threats to the stability of the rural areas remain the same after the uprisings, with the introduction of ENPARD in 2012 the logic of integrated rural development shapes a new path for framing the development of AMPs' countryside.

However, the operationalisation of the new framework through ENPARD so far has brought mixed results. On one hand the new frame played a positive role for improving the national strategies for rural development. Yet at the same time the selective collaboration of the EC with epistemic communities based mainly in Europe encourages an inward-looking attitude for providing solutions to AMPs. This approach undermines the EU efforts to support small producers. The programme expands the export basis of the partner countries, but the changes that it brings do not discourage clientelist practices and they do not mitigate significantly the centralisation of power in local rural societies.

As the literature about the agricultural component of Euro-Mediterranean relations focuses predominately on trade-related issues (Emlinger et al, 2008; Gillespie, 1997) and not on the EU rural development initiatives in the AMPs, this article employs a qualitative methodology that focuses on the analysis of the official documents produced by the EU and the Centre International de Hautes Etudes Agronomiques Mediterraneennes - Institut Agronomique Méditerranéen de Montpellier (CIHEAM-IAMM), which coordinates ENPARD. These documents are triangulated with ENP progress reports, in order to compare and evaluate the EU's work in this area before and after 2010.

For explaining the sources of the EU response to the uprisings, the article starts by tracing the ENP work before 2010 and the origins of integrated rural development. After the identification of the new framework, the paper analyses the interpretation of threats for the countryside of AMPs before and after 2010 and the role of the new (and old) actors involved in ENPARD. This analysis is followed by a section explaining the effects of ENPARD on improving the stability and security in the rural areas of AMPs. This contribution finishes by mapping the impact of the programme on AMPs.

\section{From trade liberalisation to integrated rural development: the ENP before and after the} Arab uprisings

The creation of the Euro-Mediterranean Partnership made the AAs the main pillar of the agricultural part of the Euro-Mediterranean relations. The primary aim of the agricultural 
component was the liberalisation of food trade between the EU and AMPs. The AAs mainly focused on the gradual elimination of border controls and tariffs of a certain number of food products. As a result, they left issues of deeper integration (e.g., non-tariff barriers) for the future or included them in a very general manner.

After a few years of implementation, it became obvious that the AAs did not meet the expectations of policymakers. The protectionist approach of some EU states is often cited as the main problem in the negotiations between the EC and AMPs (Gillespie, 1997; Joffé, 1998; Montanari, 2007; Tovias, 1997). However this is not the only factor hindering agricultural trade liberalisation. Another important problem is the existence of non-tariff barriers within AMPs (such as low food standards and regulations incompatible with the EU rules) (Emlinger et al., 2008). Addressing these problems was the main priority on the agenda of the Ministers of Agriculture of the EU and the Mediterranean partners in the First Euromed Conference in Venice in 2003. There it was agreed that further negotiations for the liberalisation of agricultural trade should be complemented by the reduction of non-tariff barriers.

The initiation of the ENP in 2004 as a policy that would integrate deeper AMPs into the EU market added a second pillar to the agricultural part of the Euro-Mediterranean relations. The Action Plans (APs) signed between the EU and AMPs complemented the AAs and aimed to confront all the non-tariff aspects of agricultural trade discussed in Venice. In exchange for a larger stake of the EU market the APs required similar actions by AMPs. These were related to administrative support to farmers, the improvement of sanitary and phyto-sanitary controls (SPS) and measures encouraging private investment in agriculture. These interventions aim to improve food safety requirements and facilitate trade in agricultural products with the EU (European Commission, 2004, 2004).

The progress that AMPs have made in the implementation of the ENP has been uneven, as they did not embrace the strategy with the same enthusiasm. Until the uprisings Tunisia and Morocco implemented more actions of the agricultural part of the strategy, followed by Egypt and Jordan. Yet, despite the uneven pace of reforms, AMPs pursued policies that increased agricultural production and trade with the EU. The EU progress reports mention that until 2010 the AMPs reduced (selectively) non-tariff barriers in food products, they introduced SPS and their regulatory bodies received training for adjusting their legislation and standards to the EU rules (European Commission, 2009, 2010, 2011b). Furthermore, investments in agriculture were encouraged through the privatisation of state companies (such as SODEA and SOGETA in Morocco), large-scale privatisations of farming lands and 
reduction of controls for foreign investors (in Morocco and Tunisia) and land reclamation schemes (in Egypt).

The implementation of the APs improved the export capacity of AMPs, which saw their exports to European markets increase symmetrically with the pace of the ENP-led reforms. As the best performer of the ENP in the region until 2010, Tunisian food exports to the EU were increasing about 10 per cent each year (Directorate General for Trade, 2016c). During this period Moroccan and Egyptian food exports also experienced high growth (the main hickup in this trend occurred in 2009, due to the global crisis) (Directorate General for Trade, 2016a, 2016b).

Yet, the greater stake of the EU market that the partners were getting benefited only a small segment of the Arab Mediterranean rural population. Even if many analysts argued that the profits from the openness of Arab Mediterranean trade to the EU (and global markets) were captured primarily by local business and political elites (Bush, 2004, 2007, p. 200; Desrues, 2005), the initial response of EU member states after the Arab uprisings was of scepticism about any potential changes of the existing EU programmes. This is evident in the Annex of the conclusions of the first European Council meeting after the death of Mohammed Bouazizi in December 2010. On 4 February 2011, member states agreed that the EU relationship with the Southern partners of the ENP should be based on the 'principles set out in the Association Agreement and the commitments made' (European Council, 2011a, p. 14).

It was the EC that a few months after the revolts linked 'the unrest in several Southern Mediterranean countries [...] to economic weaknesses' (European Commission, 2011a, p. 7). In its first strategy paper about the reaction of the EU to the Arab uprisings it stressed the need for a more precise focus of the APs on fewer actions with more specific benchmarks (European Commission, 2011a, p. 18). Three days after the release of the strategy paper, EU member states gave the green light to the EC to review the existing programmes in order to focus on the present needs of the ENP partners (European Council, 2011b, p. 5).

The focus on the present needs of the ENP partners and the suggestions for fewer actions were accompanied by more emphasis on inclusive growth, job creation and the role that SMEs could play in the inclusive economic development of Arab Mediterranean societies (European Commission, 2011a). For the agricultural aspect of the ENP, the EC was determined to draw lessons from previous EU experience and from programmes which helped the accession of the new member states (NMS) (Clarke, 2012; European Commission, 2011a). In support of this approach the European Parliament (EP) stressed that poverty is 'a persistent evil in the countryside' (Rinaldi, 2012) and assistance to SMEs is crucial in dismantling existing 
oligarchies. The EP called the EU to contribute to the development of a healthy agricultural production and rural development in the region 'in order to strengthen the stabilisation process' (Rinaldi, 2012). Several voices in other EU institutions highlighted the need 'to foster an agricultural sector geared to small farmers' (Narro \& Moreno, 2014, p. 18)

Towards this direction the EU initiated ENPARD in 2012 and the programme became the main vehicle that demonstrated the EU's commitment to inclusive growth and stability in its neighbourhood. According to the former Commissioner for Agriculture and Rural Development Dacian Cioloş, with ENPARD:

\footnotetext{
the European Commission sends a very clear signal of our willingness to put agriculture at the heart of our relationship with our neighbours and friends [...] ENPARD programmes are not merely about funding, but also about working methods, which have been shown to be effective, in particular during the accession of the new EU Member States. (European Commission, 2012b, emphasis added)
}

The new working methods that ENPARD attempts to introduce originate from the idea of integrated rural development. This appeared in the EU in the mid-1980s as a result of the transformation of the welfare state model and of the diverse rural experiences across Europe. Besides the privatisation of state companies, a key aspect of this transformation was a change of focus from government to governance (Jones, 2000; OECD, 2006; Ward \& McNicholas, 1998).

This change indicated two things. First, the era of large-scale state investments in infrastructure was coming to an end and subnational agro-commercial regions and centres were forced to design sustainable social and economic policies and development plans (Ray, 2000). Second, the diverse rural experiences in Europe signalled that rural development could not be perceived any more as an automatic result of an increase in agricultural production, but as a multidimensional process with economic, social and environmental parameters (such as improvements in distribution of income, equitable access to resources, sustainable use of resources and production). The word 'integrated' emphasised that previous sectoral policies that were organised by central authorities were often disjointed and failed to address these parameters in a holistic manner. The new approach saw these issues as parts of a master plan that should be coordinated at the local level.

For the successful coordination of the various sectoral actions that meet diverse needs and circumstances (such as improvements in infrastructure, credit schemes, training of 
farmers, irrigation programmes and initiation of environmental standards) the concept advocated the mobilisation of local actors that were encouraged to form partnerships with the state, the private and the third sectors. The active participation of local farmers is an essential component, as they can provide solutions that are contextualised according to their needs. The argument of the EC was that this new integrated framework has a strong element of endogenous development, as it incorporates local knowledge and it allows the creation of networks which provide better and more innovative solutions that address the particular challenges of rural areas.

In practice the first integrated rural development programme appeared in the EU in 1982 (Ward, 2002), but the new model was established with the introduction by the EC of the Liaison Entre Actions de Développement de l'Économie Rurale (LEADER) in 1991. Initially as a three-year programme, which has been prolonged until today (as LEADER II and LEADER+) LEADER exemplified the integrated rural development approach of the EU. The initiative focused on areas of less than 100,000 people and supported small-scale projects (European Network for Rural Development, 2014). The participation of local farmers was ensured through the operation of Local Action Groups (LAGs), which formed partnerships between the public, voluntary and business sectors and carried out the suggested business plans.

During the first period of LEADER (1991-1994), more than 600 LAGs were approved for funding across the EU. This number grew significantly during LEADER II (1995-2000) and LEADER+ (2000-2006) covering more than 890 LAGs in the old member states (Ray, 2000). After 2007, LEADER was extended to the NMS and to candidate countries as part of the preaccession rural development programmes.

By mentioning the previous EU experience, Commissioner Cioloş was highlighting the bottom-up approach of LEADER and the space that it provides for partnerships at the subregional level between the public, private and civil sectors. This new working method could give the opportunity to small farmers and local actors of AMPs to influence decisions in states dominated by centralised decision-making processes and to improve the local rural economies (EU Neighbourhood Info Centre, n.d.-a).

As ENPARD follows LEADER's conceptual framework for stimulating the agricultural activities of small farmers in AMPs, it also shares its principles. The principles of ENPARD are long-term policy planning, integrated approach to rural development and the participation of civil society organisations (CSOs) in both the decision-making and implementation of the programme (CIHEAM-IAMM, n.d.). 
If one looks at the amount of funds that the EU committed to ENPARD, it would be tempting to dismiss it as of no great significance for the development of the Arab Mediterranean countryside. For the start-up phase of the programme and for fostering political dialogue between different actors the EU has allocated $€ 2.8 \mathrm{~m}$ from 2012-2014 and $€ 4 m$ from 2015-2020 (EU Neighbourhood Info Centre, n.d.-a, n.d.-b). The first four countries that have implemented ENPARD are Jordan, Egypt, Tunisia and Morocco and the funds that the EU has committed to the two countries subject to regime change are indicative. From the beginning of ENPARD and until today the EU has offered to Tunisia $€ 25 \mathrm{~m}$ and to Egypt $€ 36 \mathrm{~m}$. Important is also the fact that these two countries have selected more areas than the two other AMPs. The pilot areas in Tunisia are Ain Draham, Bargou, Kerkennah, Kébili Nord, Médenine and Jendouba and in Egypt are Matrouh, Minia and Fayoum. The Jordan authorities have selected Ajloun and Tafilah and Morocco has decided to follow a non-territorial approach. For Morocco the ENPARD funds are added to technical assistance of $€ 70 \mathrm{~m}$ for supporting the Green Morocco Plan (Plan Maroc Vert), which covers the entire country (CIHEAM-IAMM, n.d., n.d.).

Algeria and Lebanon have joined one year later (in 2013) and they receive fewer funds from ENPARD. Algeria gets $€ 10 \mathrm{~m}$ for employment in rural areas of Ain-Témouchent, Laghouat Setif and Tlemcen ("Programmes for Technical \& Financial Support," n.d.). Lebanon has finalised its working plan at the end of 2013 and it has agreed to extend the programme for one year. Within this period the focus of ENPARD was on building the capacity of the Ministry of Agriculture. In $2014 € 6.8 \mathrm{~m}$ were allocated for supporting local SMEs and cooperative schemes (Women Economic Empowerment Portal, 2014). After an EC invitation in July 2015, the Palestinian authorities decided to join the programme and a kick off seminar was organised in 2016. At the moment of writing only the priority themes have been identified for the implementation of ENPARD and only preliminary meetings have been held between stakeholders (CIHEAM-IAMM, n.d.). In all ENP countries the operational programmes of ENPARD are funded by the ENI, SPRING, cooperation tools (such as TAIEX and TWINNING) and co-financed by the ENP countries (CIHEAM-IAMM, n.d.).

However, the emphasis that the EU puts on the enactment of the new frame for the rural development of the AMP goes beyond the current funding cycle. ENPARD has become an essential component of the Deep and Comprehensive Free Trade Agreements that the EU negotiates with all the ENP partners, as it attempts to address the various threats in the rural areas of neighbouring countries. The new working method entails a change in the EU's conceptual framework, as it indicates that the EU was willing to give more room to small 
farmers and local authorities over the design and implementation of rural development projects. However, this conceptual framework does not suggest a different understanding of the main threats for the rural areas of the AMPs, but a way to address them. This is discussed in the next sections.

\section{EU threat perception before the Arab uprisings: the ENP as a top-down and ineffective policy}

The importance of agriculture in the economy of AMPs has for many years been acknowledged by the EU. Yet, the economic crises that hit these countries after 2010 increased regional disparities, inequality and poverty rates and they highlighted the multidimensional character of stability and security in rural areas.

Stability and security in rural areas have an economic, a political and an environmental dimension. These dimensions are interlinked and cover food security, rural poverty and unemployment, decentralisation of the decision-making process for rural development, cooperation between rural areas, social inclusion of vulnerable groups (such as women and youth) and sustainable production.

The ENP country reports have helped the EU to identify the nature of these threats and their impact in each ENP partner. Rural poverty and unemployment hit especially youth and women in AMPs. For example, at the beginning of the policy 63 per cent of the Moroccan children were out of secondary school in rural areas contrary to 24 per cent in the urban areas. In the pilot areas of ENPARD school enrolment in secondary education does not exceed 50 per cent of female students whereas in the urban areas of Egypt, Tunisia and Morocco the number is higher than 70 per cent ("Education Policy Data Center," 2012; UNICEF, 2013a, 2013b).

Food security has not been seen simply as the failure of agriculture to produce sufficient food at the national level, but as the failure of the state to guarantee access to sufficient food at the household level. Availability, access and affordability are elements of food security and the EU has recognised since the beginning of the ENP the complex interlinkages between the individual, community, national and international levels (European Commission, 2004a, 2004b, 2005). Similarly, the decentralisation of the decision-making process and social inclusion are concepts that have come of age and all the mainstream donors include actions for helping vulnerable people to gain access to a range of activities regarded as typical for their societies. 
The definition of these threats in the country reports informed the construction of the APs, which included actions for increasing the stability and security in rural areas. Yet, despite their tailored design, the APs suffered from several weaknesses. They envisaged actions without specific benchmarks and the EU's approach was top-down and deterministic.

This method undermined the efforts of the EU. The absence of specific benchmarks in the APs meant that the partner countries did not need to provide any milestones for their annual reforms or national plans that indicate how they specifically address problems in rural areas. As a result threats such as food (in)security, rural poverty and unemployment were dealt indirectly with emphasis being put on the benefits of economic growth and food price stability for increasing the purchasing power of the poor in rural areas and for creating more jobs. At the same time the top-down approach of the EU allowed on the one hand the central authorities of partner countries to remain the main conduits of assistance for rural development, and on the other hand the state elites to reproduce their power in rural areas at the expense of vulnerable groups. Indicative of this approach are the conclusions of the report of the European Court of Auditors (ECA) about the cooperation of the EU with Egypt before 2011 (European Court of Auditors, 2013a). ECA noticed that the EU interventions had given little attention to women and funds channelled through CSOs 'were not sufficient to make a discernible difference' (European Court of Auditors, 2013b). From 2007 until 2010 zero funds were given from the European Neighbourhood and Partnership Instrument (ENPI) (the main EU aid tool for the ENP countries) for rural development, local community development, to agricultural SMEs and to serious environmental threats in rural areas (such as waste management). In the same vein, ECA was critical of the EU's tolerance to the corrupted practices of the Egyptian mechanism. ECA mentioned that:

Lack of budgetary transparency, an ineffective audit function and endemic corruption were all examples of these undermining weaknesses. The Commission and the European External Action Service (EEAS) did not react to the lack of progress by taking decisive action to ensure accountability for considerable EU funds, which continued to be paid directly to the Egyptian Authorities. (European Court of Auditors, 2013b)

The importance of regime stability as a way of maximising EU security is underlined in the introduction of this special issue. In the case of rural development the EU approach had a dual impact on the Arab Mediterranean countryside. First, it allowed the regimes of AMPs to reproduce their power by managing the allocation of the EU funds and the selection of priority 
areas. Second, the deterministic assumption of EU policymakers that a higher stake of the EU market for the food products of partner countries would have a trickle-down effect and could improve living conditions in the Arab Mediterranean countryside led ENPI funds predominantly towards the parts of the APs that focused on the facilitation of trade, modernisation of agriculture and the SPS system. This situation proved inadequate to increase the stability of rural areas before the uprisings.

\section{EU threat perception after the Arab uprisings: new actors, different treatment?}

As part of the ENP, ENPARD also suggests that a greater stake of the EU market offers solutions to the perennial problems of Southern partners. In addition, the new programme does not offer a new understanding or definition of the aforementioned threats. However, the frame of integrated rural development that ENPARD puts forward introduces new actors in the decision-making process and a new method to address problems in rural areas.

The EC attempt to draw lessons from LEADER for reducing the vagueness of the APs brought closer Directorate General (DG) Agri and DG DEVCO (especially Unit F responsible for the development of neighbourhood countries). The experience that the two DGs had in working with CSOs (through the LEADER programmes in the candidate countries for DG Agri and through the provision of assistance to developing countries for DG DEVCO) opened the decision-making process to civil society actors involved in the pre-accession programmes of the candidate countries and with experience in the rural development of AMPs. However, these CSOs had minimal input on the construction of the ENP APs, the priorities of which were negotiated by the EEAS and the state authorities of the AMPs. CIHEAM-IAMM in Montpellier, one of four institutes part of the International Centre for Advanced Mediterranean Agronomic Studies, with experience in the LEADER programmes of accession countries and with ties to rural institutes in AMPs, was contracted by the European Commission to develop the first programme of actions and to foster the political dialogue between the EU and the ENP Southern partners regarding their rural development (CIHEAMIAMM, 2012b).

This situation created a new organisational pyramid with the EU institutions and European epistemic communities at the top, which manage to influence the direction of the new tool. The reports prepared by CIHEAM-IAMM reproduce the narratives of the previous country reports. For example, the new reports highlight the need for more food exports in order to ameliorate threats such as food security, rural poverty and unemployment. Yet, contrary to previous practices, the new reports suggest a different treatment recommendation 
for increasing the standards of living of rural populations. They advocate the inclusion of local communities in the identification of priorities and solutions, which is consistent with the logic of integrated rural development (CIHEAM-IAMM, 2012a).

Towards this direction, in its start-up phase (2012-2014) CIHEAM-IAMM with the help of DG Agri and DG DEVCO organised frequent meetings with different stakeholders in the EU and the AMPs for the development of rural areas. These organisations included trade and labour unions of AMPs, such as the unions of exporters, small farmers' syndicates and NGOs active in rural areas, such as the Coptic Evangelical Organisation of Social Services in Egypt and the 'Action and Solidarity Development' in Tunisia (CIHEAM-IAMM, 2014). Equally, in countries where ENPARD entered its second phase (e.g., Morocco), CIHEAM-IAMM held meetings with public servants and CSOs that operate in rural areas.

However, there is a critical difference between the rhetoric of participation and giving real power to rural communities to affect the outcome of the process. In the case of ENPARD consultation meetings and informing practices help the new (and old) powerholders to claim that all sides were considered, but critical elements of the threats in rural areas and the solutions that ENPARD implements are already decided by epistemic communities and technocrats, who are mainly based in the EU. This arrangement enables these actors to maintain their position on the top of this hierarchical structure.

A key example of this tendency is the ENPARD's rhetoric that frames 'small farmers' skills' as problems for the sustainable development of rural areas. Similarly to the deterministic view of the EU before the Arab revolts, this rhetoric creates a particular business-oriented discourse for dealing with threats in rural areas that diminishes the capacity of local actors to provide solutions and influence the decision-making process.

In ENPARD it is mentioned that the poor managerial skills of small farmers increase solid and agricultural waste and lead to overuse of chemical inputs and environmental degradation (European Commission, 2013a). Therefore, small farmers are unable to provide environmentally sustainable solutions (European Commission, 2013). As a result ENPARD offers the opportunity to think tanks in ENP countries to collaborate with CIHEAM-IAMM for driving 'a process of analysis, capitalization and counseling that meets the policy-makers' needs and expectations' (“The ENPARD South support programme phase II," n.d.).

This narrative puts CIHEAM-IAMM in the driving seat and despite the rhetoric of the new integrated approach, ENPARD continues the work of policies introduced before 2010. For example, the solution suggested for making food production more sustainable is the adoption of Good Agricultural Practices (GAPs) (CIHEAM-IAMM, n.d.; EU Neighbourhood 
Info Centre, 2015b, 2016). GAPs are not an abstract concept subject to negotiations between small farmers and other stakeholders. It is a set of codes, standards and regulations developed in recent years by the food industry and producers organisations. ENPARD supports the establishment of certification programmes (such as EurepGAP), which are developed by major European retailers.

In addition, ENPARD encourages advisors to tie agricultural research and training workshops of small farmers to the ideas of competition, risk and productivity (CIHEAMIAMM, n.d.). Before 2010, the TWINNING programmes were doing the same work in AMPs. In Egypt, TWINNING offered technical assistance to the national centre 'in order to better observe market needs and expectations, analyse market dynamics along with consumer habits, and provide public authorities with risk-assessment reports and innovative ideas for policy development' (İşleyen, 2015, p. 682). According to İşleyen TWINNING programmes treat 'local' as a problem for the development of rural areas and the allocated funds lead to patterns of neoliberal governmentality (İşleyen, 2015).

ENPARD interventions continue the implementation of the SPS controls of the past for dealing with threats in rural areas, but contrary to the previous approach, they introduce more specific benchmarks and they focus on the local level. This new approach gives the capacity to the EU to be more efficient. GAPs codify agricultural practices at farm level for a range of commodities. Their purpose varies from fulfilment of trade and government regulatory requirements (in particular with regard to food safety and quality), to more specific requirements of specialty or niche markets. In the more advanced countries that implement the programme (such as Morocco) specific regions have become pilot areas (Fes Boulemane, Meknes-Tafilalet, Oriental and Souss-Mass-Draa) for training agricultural advisors and specific benchmarks have been introduced. For example, in Morocco one advisor is allocated for every 1350 farmers and a minimum number of women is introduced among rural advisors (CIHEAM-IAMM, n.d.). Similarly in other countries the local rural cooperatives that will apply the GAPs have been already selected.

This new hierarchical mode has put new actors at the top of the decision-making process. These actors have determined both the definition of threats for rural areas after 2010 and the remedies that must be applied in partner countries. This process has been driven by a technocratic ratchet mechanism that fits new information into existing cognitive frames. Instead of allowing farmers to effectively voice their views, powerholders conduct programmes, which aim to educate or 'cure' the participants in partner countries. This situation has significant material impact on small farmers, and despite the fact that ENPARD 
attempts to bypass central authorities for the development of rural areas, it does not seriously challenge the status quo in partner countries. This impact of the programme is discussed in the following section.

\section{The paradox of top-down direction for bottom-up implementation and its effects}

ENPARD's project-based approach has started to shape the national strategies of ENP countries and has helped them to integrate activities that were not envisaged in the APs. As mentioned earlier, before ENPARD the EU mainly supported top-down policies, which encouraged structural changes within agriculture (European Commission, 2004, 2004, 2006). These approaches were typically sectoral meaning that they supported schemes decided at the national level for the increase of the agricultural output without taking into consideration winners and losers of structural reforms in agriculture. In other cases, the EU financed standalone projects, which were not an integral part of national or regional strategies (such as irrigation projects with questionable results for small farmers). On the other hand, the bottomup approach of ENPARD entails that its activities are contained in local strategies, which then inform the national strategy for the rural development of partner countries. The new frame of integrated rural development concerns actions that involve different environmental, economic and social sectors.

In three of the four countries that have joined the programme, environmental risks have been addressed more concretely and positive changes have been traced in national plans. In Egypt, the introduction of the Joint EU Rural Development Programme through ENPARD has resulted in policy measures at the national level regarding the more efficient management of water and waste in rural areas. In Tunisia and Morocco where ENPARD has entered its second phase, the programme has helped to highlight the training of small farmers and the sustainability of resources as the main axes of the national strategies for the development of rural areas (EU Neighbourhood Info Centre, 2015a). In Jordan, there is not much evidence of change yet in the national strategy of the country. According to CIHEAM-IAMM, ENPARD is still in a phase of training local actors how to take more ownership of sectoral strategy documents and shape policymaking (CIHEAM-IAMM, n.d.).

Regarding economic threats, the focus of ENPARD on SMEs has brought back to the agenda the issue of rural poverty, neglected in the ENP APs and by partner countries (Pellissier \& Gargano, 2015). One of the two main axes of the programme focuses on the diversification of the economic activity in rural areas and the creation of agricultural cooperatives and advisory services to small farmers for mitigating rural poverty. Compared 
to the APs, this approach is a big leap forward, as the APs have only helped large farmers of AMPs to get a bigger stake of the EU market (Kourtelis, 2015; Narro \& Moreno, 2014). To the more advanced AMPs, such as Morocco and Tunisia, the programme has already contributed to the establishment of advisory services in the pilot areas, the registration of agriculture cooperatives and awareness campaigns for the benefit of small farmers' cooperation.

Yet the other axis of the programme, which focuses on agricultural productivity, market efficiency and standards contradicts the efforts of the EU to strengthen local agricultural cooperatives. In an effort to link the Mediterranean to international markets and to keep its promise for offering a greater stake to the EU market for Arab farmers, ENPARD offers funding only to projects that increase the production of commercial crops destined to international markets. The problem here is that in some cases the identification of these crops (e.g., figs and olives in Tunisia) has been made at very early stages of the programme and before the creation of LAGs (CIHEAM-IAMM, n.d.). This situation raises doubts about the inclusion of small farmers in the consultation process and illustrates the significance of epistemic communities in decision-making. In addition, the second axis of ENPARD promotes EU food safety and quality standards. Their rigorous implementation does not only question the participatory ethos of ENPARD, but has also economic implications.

The Food and Agriculture Organisation of the United Nations (FAO) and many analysts warn that despite the benefit of offering access to international markets, the rigorous implementation of GAPs and quality standards has often increased production costs and the risk of small producers not seizing market opportunities (Amekawa, 2009; FAO, 2008; Graffham, Karehu \& MacGregor, 2007). These costs relate to technical training for innovative production and hygiene practices, variable inputs such as safer yet more costly pesticides, structures such as grading sheds, disposal pits and pesticide storage units, as well as periodical certification and accreditation (Amekawa, 2009).

In the case of ENPARD the minimal funding that cannot cover these high investments and the uncertain picture after the end of the programme are not the only problems for small farmers. It is a structural challenge that emerges for small producers from the implementation of the EU initiative. By being forced to produce specific crops and follow standards decided in the EU, the formulation of small LAGs does not help much small farmers to elude market mechanisms, for instance by agreeing beforehand on procedures, the fixing of bids for tender and the allocation of local resources, and in this way to create a sort of local-scale corporatism that can lead to more inclusive growth. In addition, and even if ENPARD broadens the export 
basis of AMPs, a large number of small and subsistence farmers that do not produce commercial crops are excluded from such projects and from participating in LAGs.

Another area of concern for ENPARD's contribution to the stabilisation of the Arab Mediterranean rural areas is that the programme follows the more-for-more doctrine of the EU towards the region. This conditional approach threatens the regional dimension of ENPARD and it indicates that the EU's selective engagement does not determine only the role of the related actors, but also the operation of the tool across countries. AMPs that have entered ENPARD at a later stage (Algeria, Lebanon and Palestine) have received less funding than other states and their slower progress regarding capacity building makes it more difficult to compete for additional funds from ENPARD. As a result ENPARD increases divergence between participant countries.

The territorial basis of ENPARD has helped policymakers to identify regions that are indeed in much need of EU funds. For example 83 per cent of rural poor in Egypt live in Upper Egypt (Ghanem, 2014) and the three areas that receive the ENPARD funds (Matrouh, Minia and Fayoum) are among the poorest in the country. Similarly in the other countries the rural people in pilot areas suffer from chronic poverty and unemployment. Yet, evidence so far show that the selected pilot areas are disconnected and the only regional element of the programme involves the sharing of best practices through conferences and workshops. Until today there are not any signs of cross-border-cooperation activities between the LAGs, which could stimulate the local markets, increase returns for small farmers and reduce rural poverty.

As ENPARD is in its initial stages, lessons from the LEADER programmes illustrate the effects of this conditional (more-for-more) approach when combined with limited funding on the power that different actors enjoy in the decision-making process. In the initial phase of LEADER the EU's contribution accounted for only 1.7 per cent of the total money allocated to rural development (Ray, 2000). Many analyses on LEADER in Italy and the NMS have underlined that competition between LAGs for the few funds of the programme worked as a barrier to their cooperation at the regional level. In fact, research shows that the combination of this competitive approach and of minimal funding brings LAGs closer to the national authorities of their countries, as it strengthens the reliance on individual relations with central authorities to secure money for their projects (Kovách, 2000; Osti, 2000).

This situation does not have only economic consequences for local areas, but also undermines ENPARD's work towards reducing the pervasiveness of centralised procedures over rural development. By functioning as such, the EU does not manage to substitute the existing hierarchical model between central authorities, local actors and CSOs, criticised by 
EU institutions and in ECA reports, with a network of actors that manages market relations in favour of smaller producers. The inclusion of research institutes and the presence of local cooperatives may increase the legitimacy of the programme, but at the same time reinforces the omnipotence of central authorities. Evidence from candidate countries and NMS shows that under such conditions the governments are in a position to select with whom they will work at the local level (Kovách, 2000; Petak, 2011).

Exclusion of CSOs in AMPs from development projects is not a new phenomenon, even if the space that the governments allow to local NGOs differs both spatially and temporally. The difference between this situation and ENPARD is that the EU initiative promotes subtle forms of containment for CSOs, which are not clearly visible, but still undermine rural democratisation. Besides the capacity of the state to facilitate the work of CSOs with close ties to the government (Hamdy, 2011), there is a threat that ENPARD can turn LAGs into an instrument promoting the preferences of well-established policy communities at the local level, as it has happened in NMS and candidate countries. Their experience shows that these policy communities are comprised by farmers, CSOs and food processing industries, which have managed to retain their power by shaping the discourse about participatory rural development and the responses of the local and central authorities (Kovách, 2000; Shucksmith, 2000). Research in AMPs illustrates that the capacity of small farmers to influence the design of rural development projects is minimal (Ghanem, 2014) and the participation of CSOs does not necessarily contributes to the building of autonomous rural organisations capable of representing the diverse interests of the rural poor and amplifying their voices in public policy processes. Without careful management ENPARD can repeat mistakes of other rural programmes in these countries, which at the end did not lead to partnerships between political and civil society. According to Bergh such programmes blurred the boundaries between political and civil society in rural areas and encouraged:

elite capture and the expansion of clientelist practices, all of which stands in sharp contrast to the assumed positive outcomes of decentralization and participation policies and the prospect of accountable co-governance. (Bergh, 2010, p. 741).

The last issue that deserves attention is the role that ENPARD can play in the livelihood of vulnerable groups, such as women and rural youth. The aim of ENPARD is to offer training to women and young people from ENP countries. The related documents mention the 'particular attention that is paid to the inclusion of young people [...] and women [...]. These 
groups are explicitly targeted in several programme activities such as professional training' (CIHEAM-IAMM, n.d.; European Commission, 2013), and in some cases (e.g., Morocco) women are trained as agricultural advisors. Further details about the organisation of these training workshops are not available yet, but again previous experience shows that in many cases women are underrepresented and their non-involvement is a result of low levels of schooling or persisting illiteracy (Hartl, 2009). According to UNICEF, the literacy level of Tunisian women (96.1 per cent) is higher than that of other participant countries (UNICEF, 2013a, 2013b) and based on these facts, the Tunisian training programme has more chances for success. However, the design of the training sessions and access to credit are matters of paramount importance for the improvement of living conditions in rural areas. Projects funded by the UN with similar goals to ENPARD (such as the Oued Sbaihya project in Tunisia) generated processes of both inclusion and exclusion. Women that lived in households with small land and low income were found in a worse position and with greater debts after the application of the programmes (Gana, 2012) or they did not qualify for loans to pursue their own initiatives and their income remained low (Hartl, 2009; Khafagy, 2009). Often the skills that rural youth and women acquire from such technical workshops prepare them for off-farm working and lead to urbanisation rather than to a reduction of chronic poverty.

\section{Conclusion}

After the Arab uprisings the EU put the promotion of inclusive growth and support to small producers higher on its agenda. For the agricultural part of the ENP, the EU designed a new regional programme to support small farmers and address the security and stability threats in rural areas of AMPs. The inclusion of epistemic communities and CSOs has influenced the cognitive framework of ENPARD. These actors adopted an integrated strategy for the rural development of AMPs, which was developed in the EU since the beginning of the 1980s and implemented through the LEADER programmes since the 1990s. Based on lessons from LEADER, the new programme envisaged to mitigate the security risks that threaten stability in the countryside of the Southern rim of the ENP by adopting a multi-sectoral and participatory approach for development. Fundamental to the success of the programme is the opening of the decision-making process to local actors.

During its first years of existence, ENPARD's new framework for rural development has managed to bring some positive measures and shape the focus of national strategies regarding environmental degradation and rural poverty. However, the attention of the EU to improvements of reforms that existed before 2010 and its selective engagement with particular 
actors limit the success of the programme. The insistence of the EU on the more-for-more approach and on the promotion of regulations that are designed in the EU expands the export basis of AMPs, but undermines regional cooperation and inclusive growth. At the same time, the EU engagement primarily with epistemic communities based in Europe and with national authorities of ENP countries shapes unevenly the discourse about rural development. Paraphrasing Haas these epistemic communities generate consensual knowledge (Haas, 1992), but as it is the case in other EU policy areas, experts' opinions primarily reinforce institutional choices and consolidate bureaucratic power (Verdun, 1999). Within ENPARD this approach allows new patterns of exclusion to emerge from the attempted decentralisation of the decision-making process. As a consequence stakeholders' involvement is asymmetrically realised in practice. This situation indicates that after the revolts, the implementation of the new EU frame of integrated rural development only partially addresses the politico-economic threats in rural areas of Southern partner countries.

\section{Acknowledgements}

I am very grateful to the anonymous reviewer and the editors of the special issue for their insightful comments on earlier drafts. I would also like to thank the two discussants - Leila Simona Talani and Federica Bicchi - for their comments and the questions they raised at the workshop that was organized in May 2016 at King's College London. 


\section{References}

Amekawa, Y. (2009). Reflections on the Growing Influence of Good Agricultural Practices in the Global South. Journal of Agricultural and Environmental Ethics, 22(6), 531.

Bergh, S. I. (2010). Assessing the Scope for Partnerships Between Local Governments and CommunityBased Organizations: Findings from Rural Morocco. International Journal of Public Administration, 33(12-13), 740-751.

Bush, R. (2004). Society and the uncivil state: land tenure reform in Egypt and the crisis of rural livelihoods (Civil Society and Social Movements Programme Papers No. 9). Geneva: FAO. Retrieved from http://agris.fao.org/agris-search/search.do?recordID=GB2013203743

Bush, R. (2007). Politics, power and poverty: twenty years of agricultural reform and market liberalisation in Egypt. Third World Quarterly, 28(8), 1599-1615.

CIHEAM-IAMM. (2012a). Enjeux de l'économie politique agricole, alimentaire et rurale dans les pays arabes méditerranéens (Algérie, Egypte, Jordanie, Liban, Maroc et Tunisie) Document préparé par l'équipe CIHEAM-IAMM. Montpellier: CIHEAM-IAMM.

CIHEAM-IAMM. (2012b). Implementation of the ENPARD Programme by CIHEAM-IAMM Operator for DG DEVCO F2. Montpellier: CIHEAM-IAMM.

CIHEAM-IAMM. (2014). CIHEAM-IAM Montpellier. Retrieved April 3, 2016, from https://www.iamm.fr/content/search?SearchText=enpard

CIHEAM-IAMM. (n.d.). Activities in Lebanon. Retrieved July 30, 2016, from http://www.enpard.iamm.fr/en/activities/national-dialogue/lebanon

CIHEAM-IAMM. (n.d.). ENPARD PILOTE ACTION PROGRAMME IN TUNISIA. Retrieved September 4, 2016, from http://www.enpard.iamm.fr/en/activities/programmes-fortechnical-and-financial-support/110-pilote-action-programme-tunisia

CIHEAM-IAMM. (n.d.). ENPARD South. Retrieved May 13, 2016, from http://enpard.iamm.fr/en/presentation/appoach-objectives

CIHEAM-IAMM. (n.d.). ENPARD South Activities in Jordan.

CIHEAM-IAMM. (n.d.). ENPARD Tunisia: The pilot Action Programme under ENPARD. CIHEAMIAMM.

CIHEAM-IAMM. (n.d.). Good agricultural practices in Mashreq. Retrieved July 30, 2016, from http://enpard.iamm.fr/en/news-and-events/197-gap-mashreq

CIHEAM-IAMM. (n.d.). Morroco - The supporting programme to the national strategy on agricultural advisory $\begin{array}{llll}\text { services. } & \text { Montpellier: } & \text { CIHEAM-IAMM. }\end{array}$ http://www.enpard.iamm.fr/images/docs/EN/enpard_morocco_en.pdf

Clarke, J. (2012, May). European Neighbourhood Programme for Agriculture and Rural Development ENPARD. Presented at the Senior Officials Conference on ENPARD, Brussels.

Desrues, T. (2005). Governability and Agricultural Policy in Morocco: Functionality and Limitations of the Reform Discourse. Mediterranean Politics, 10(1), 39-63. 
Directorate General for Trade. (2016a). European Union, Trade in goods with Egypt. Brussels: European Commission. Retrieved from http://trade.ec.europa.eu/doclib/docs/2006/september/tradoc_113375.pdf

Directorate General for Trade. (2016b). European Union, Trade in goods with Morocco. Brussels: European Commission. Retrieved from http:/ / trade.ec.europa.eu/doclib/docs/2006/september/tradoc_113421.pdf

Directorate General for Trade. (2016c). European Union, Trade in goods with Tunisia. Brussels: European Commission. Retrieved from http://trade.ec.europa.eu/doclib/docs/2006/september/tradoc_122002.pdf

Education Policy Data Center. (2012). Retrieved January 27, 2017, from http:/ / www.epdc.org/

Emlinger, C., Jacquet, F., \& Lozza, E. C. (2008). Tariffs and other trade costs: assessing obstacles to Mediterranean countries' access to EU-15 fruit and vegetable markets. European Review of Agricultural Economics, 35(4), 409-438.

EU Neighbourhood Info Centre. (2015a, November 26). Agriculture and Rural Development: ENPARD to launch second phase in Morocco. Retrieved December 3, 2016, from http://www.enpiinfo.eu/medportal/news/latest/42894/Agriculture-and-Rural-Development:-ENPARD-tolaunch-second-phase-in-Morocco

EU Neighbourhood Info Centre. (2015b, December 18). Supporting agriculture: second phase of ENPARD programme kicks off in Egypt. Retrieved July 30, 2016, from http://www.enpiinfo.eu/medportal/news/latest/43035/Supporting-agriculture:-second-phase-of-ENPARDprogramme-kicks-off-in-Egypt

EU Neighbourhood Info Centre. (2016, May 27). Lebanon: EU programme supports development of Good Agricultural Practices. Retrieved July 30, 2016, from http://www.enpiinfo.eu/medportal/news/latest/45253/Lebanon:-EU-programme-supports-development-ofGood-Agricultural-Practices

EU Neighbourhood Info Centre. (n.d.-a). ENPARD SOUTH - European Neighbourhood Programme for Agriculture and Rural Development. Retrieved July 26, 2016, from http://www.enpiinfo.eu/mainmed.php?id=739\&id_type=10

EU Neighbourhood Info Centre. (n.d.-b). Support to the European Neighbourhood Programme for Agriculture and Rural Development (ENPARD). Retrieved July 21, 2014, from http://www.enpi-info.eu/mainmed.php?id=582\&id_type=10

European Commission. (2004). EU/Morocco Action Plan. Brussels. Retrieved from http://ec.europa.eu/world/enp/pdf/action_plans/morocco_enp_ap_final_en.pdf

European Commission. (2004a). "European Neighbourhood Policy" Country Report Morocco (No. SEC(2004) 569). Brussels: European Commission.

European Commission. (2004b). "European Neighbourhood Policy" Country Report Tunisia (No. SEC(2004) 570). Brussels: European Commission. 
European Commission. (2004). EU/Tunisia Action Plan. Brussels. Retrieved from http://ec.europa.eu/world/enp/pdf/action_plans/tunisia_enp_ap_final_en.pdf

European Commission. (2005). "European Neighbourhood Policy" Country Report Egypt (No. SEC(2005) 287/3). Brussels: European Commission.

European Commission. (2006). EU/Egypt Action Plan. Brussels. Retrieved from http://ec.europa.eu/world/enp/pdf/action_plans/egypt_enp_ap_final_en.pdf

European Commission. (2009). Mise en cuvre de la politique européenne de voisinage en 2008 Rapport de Suivi Maroc (No. SEC(2009) 520/2). Brussels: European Commission.

European Commission. (2010). Implementation of the European Neighbourhood Policy in 2009 Progress Report Egypt (No. SEC(2010) 517). Brussels: European Commission.

European Commission. (2011a). A New Response to a Changing Neighbourhood A review of European Neighbourhood Policy (No. COM(2011) 303). Brussels: European Commission.

European Commission. (2011b). Mise en oeuvre de la politique européenne de voisinage en 2010 Rapport pays :

Tunisie (No. SEC(2011) 652). Brussels: European Commission.

European Commission. (2012a). Delivering on a new European Neighbourhood Policy (No. JOIN (2012) 14 final). Brussels: European Commission.

European Commission. (2012b, June 1). ENPARD Conference on Strategic Modernisation of Agriculture in EU Neighbourhood countries (31/05-01/06/2012, Brussels). Retrieved March 3, 2013, from http:/ / ec.europa.eu/agriculture/events/enpard-workshop-2012_en.htm

European Commission. (2013). Action Fiche for the Joint EU Rural Development Programme under the ENPARD initiative. European Commission.

European Council. European Council 4 February 2011 Conclusions (2011). Brussels. Retrieved from http://register.consilium.europa.eu/pdf/en/08/st07/st07652-re01.en08.pdf

European Council. European Council 23/24 June 2011 Conclusions (2011). Brussels. Retrieved from http:/ / register.consilium.europa.eu/pdf/en/08/st07/st07652-re01.en08.pdf

European Court of Auditors. (2013a). EU cooperation with Egypt in the field of governance (No. 4/2013).

Luxembourg: European Court of Auditors.

European Court of Auditors. (2013b). EU Support for Governance in Egypt - "well-intentioned but ineffective", say EU Auditors (Press Release No. ECA/13/18). Luxembourg: European Court of Auditors.

FAO. (2008). FAO : GAP : About Us. Retrieved July 30, 2016, from http:/ /www.fao.org/prods/gap/ Gana, A. (2012). Poverty Alleviation Through Microcredit: The Impact of the Oued Sbaihya Project on the Sustainable Management of Natural Resources and Rural Women's Empowerment in Tunisia. Cornell Journal of Law and Public Policy, 22(685).

Ghanem, H. (2014). Improving Regional and Rural Development for Inclusive Growth in Egypt (Working Paper 67). Washington, DC: Brookings Institution. 
Gillespie, R. (1997). The Euro-Mediterranean Partnership: Political and Economic Perspectives. London: Routledge.

Graffham, A., Karehu, E., \& MacGregor, J. (2007). Impact of EurepGAP on small-scale vegetable growers in Kenya (No. 6). London: DFID.

Haas, P. M. (1992). Introduction: Epistemic Communities and International Policy Coordination. International Organization, 46(1), 1-35.

Hamdy, H. (2011). Civil Society in Egypt under the Mubarak Regime. Afro Asian Journal of Social Sciences, 2(2).

Hartl, M. (2009). Technical and vocational education and training and skills developent for poverty reduction - do rural women benefit? Presented at the FAO-IFAD-ILO Workshop on gaps, trends and current research in gender dimensions of agricultural and rural employment, Rome.

İşleyen, B. (2015). The European Union and neoliberal governmentality: Twinning in Tunisia and Egypt. European Journal of International Relations, 21(3), 672-690.

Joffé, G. (1998). The Euro-mediteranean partnership initiative: problems and prospects. The Journal of North African Studies, 3(2), 247-266.

Jones, O. (2000). Rural challenge(s): Partnership and new rural governance. Journal of Rural Studies, 16(2), 171-183.

Khafagy, F. (2009). Shadow NGO Report on Egypt's fourth and fifth Combined Periodic Report to The Committee on the Elimination of Discrimination against women. Cairo: Alliance for Arab Women.

Kourtelis, C. (2015). The Political Economy of Euro-Mediterranean Relations - The European Neighbourhood Policy. Basingstoke: Palgrave Macmillan.

Kovách, I. (2000). LEADER, a New Social Order, and the Central and East European Countries. Sociologia Ruralis, 40(2), 181-189.

Montanari, M. (2007). The Barcelona Process and the Political Economy of Euro-Mediterranean Trade Integration. JCMS: Journal of Common Market Studies, 45(5), 1011-1040.

Narro, P., \& Moreno, J. (2014). Opinion of the European Economic and Social Committee on "EU-Morocco Trade Relations" (own-initiative opinion) (No. 2014/C 214/03). European Economic and Social Committee. Retrieved from http://eur-lex.europa.eu/legalcontent/EN/TXT/?uri=CELEX\%3A52013IE3614

OECD. (2006). The New Rural Paradigm. OECD Publishing. Retrieved from http://www.oecdilibrary.org/governance/the-new-rural-paradigm_9789264023918-en

Osti, G. (2000). Leader and partnerships: the case of Italy. Sociologia Ruralis, 40(2), 172-180.

Pellissier, J.-P., \& Gargano, N. (2015). ENPARD South: the beginning of a long story? (Watch Letter No. 34). Montpellier: CIHEAM-IAMM.

Petak, Z. (2011). Politics of Decentralization Policy: Explaining the Limited Success of the Croatian Case after 2001. Politička Misao, 48(5), 72-84. 
Programmes for Technical \& Financial Support. (n.d.). Retrieved July 30, 2016, from http://www.enpard.iamm.fr/en/activities/programmes-for-technical-and-financial-support

Ray, C. (2000). The EU leader Programme: Rural Development Laboratory. Sociologia Ruralis, 40(2), 163171.

Rinaldi, N. (2012). On Trade for Change: The EU Trade and Investment Strategy for the Southern Mediterranean following the Arab Spring revolutions (No. 2011/2113(INI)). Brussels: European Parliament. Retrieved from http://www.europarl.europa.eu/news/en/newsroom/20120508IPR44655/meps-call-for-trade-to-build-democracy-in-arab-spring-countries

Shucksmith, M. (2000). Endogenous Development, Social Capital and Social Inclusion: perspectives from leader in the UK. Sociologia Ruralis, 40(2), 208-218.

The ENPARD South support programme phase II. (n.d.). Retrieved July 30, 2016, from http://www.enpard.iamm.fr/en/news-and-events/187-the-enpard-south-supportprogramme-phase-ii

Tovias, A. (1997). The economic impact of the Euro-Mediterranean free trade area on Mediterranean non-member countries. Mediterranean Politics, 2(1), 113-128.

UNICEF. (2013a). Statistics Egypt. Retrieved August 27, 2014, from http://www.unicef.org/infobycountry/egypt_statistics.html

UNICEF. (2013b). Statistics Tunisia. Retrieved August 27, 2014, from http://www.unicef.org/infobycountry/Tunisia_statistics.html

Verdun, A. (1999). The role of the Delors Committee in the creation of EMU: an epistemic community? Journal of European Public Policy, 6(2), 308-328.

Ward, N. (2002). Integrated rural development - a review of the literature. Trondheim: Centre for Rural Research, University of Trondheim.

Ward, N., \& McNicholas, K. (1998). Reconfiguring rural development in the UK: Objective 5b and the new rural governance. Journal of Rural Studies, 14(1), 27-39.

Women Economic Empowerment Portal. (2014, October 16). EU support to agriculture and rural development in Lebanon. Retrieved July 30, 2016, from http://www.weeportallb.org/news/eu-support-agriculture-and-rural-development-lebanon 